\title{
Soybean Oil Derivatives for Fuel and Chemical Feedstocks
}

Joanna McFarlane

Additional information is available at the end of the chapter

http://dx.doi.org/10.5772/54067

\section{Introduction}

Plant-based sources of hydrocarbons are being considered as alternatives to petrochemicals because of the need to conserve petroleum resources for reasons of national security and climate change [1]. Changes in fuel formulations to include ethanol from corn sugar and methyl esters from agricultural products are examples of this policy in the United States and elsewhere as biofuels from efficiently grown and processed biomass are claimed to be carbon neutral. In the United States, the mandate to include biofuels has been implemented as the Renewable Fuels Standards (RFS1 and RFS2) [2] with biobased diesel fuel as one of the categories. The production of biodiesel in the United States has varied considerably over the last few years, but was $241 \times 10^{6}$ gallons in the first quarter of 2012, a high number but one that still only represents $2 \%$ of the total volume of diesel fuel produced for heating and vehicles [3]. Most of the biodiesel comes from soybean oil, more than double the contribution of the other major feedstocks combined: canola oil, yellow grease, and tallow.

Replacements for commodity chemicals are also being considered, as this value stream represents much of the profit for the oil industry and one that would be affected by shortages in oil or other fossil fuels. While the discovery of large amounts of natural gas associated with oil shale deposits have reduced this as an immediate concern for instance the estimated recoverable reserves in the Western US have now reached 800x10 search into bio-based feedstock materials continues for the expected long-term benefit. In particular, this chapter reviews a literature on the conversion of bio-based extracts to hydrocarbons for fuels and for building block commodity chemicals, with a focus on soybean derived products. 


\section{Fuels}

Although commercially produced, more economical conversion of methyl esters from soybean triglycerides is an active area of research to make the product more cost competitive in comparison with standard petrochemical diesel [5]. The processes of esterification and transesterification to produce methyl esters that can be burned directly in compression -gnition engines has been reviewed elsewhere [6, 7].The fatty acid chains on the lipid molecule that constitutes soybean oil, also called a triacylglycerol or TAG, are split from the glycerol backbone and esterified with an alcohol, generally methanol, in the presence of a homogeneous base or acid catalyst, Reaction 1.

Commercial processing of biodiesel through homogeneous catalysis suffers from high feedstock costs and batch processing that requires long residence times to achieve good conversion. Hence, ongoing research continues to explore methods how to best use low-quality feedstocks, and to reduce the reagent requirements, energy usage, processing time, and complexity [8]. Figure 1 shows results from simulation of a continuous process to make biodiesel, varying temperature (a) and methanol content (b) to determine conditions for the optimal production of high quality grade biodiesel. As the process is limited by kinetics and mass transfer, the effect of mixing has also been investigated by considering the available volume fraction of reagents (c) [9], defined as the molar ratio of reagents in the reaction zone versus the overall reagent volume in the vessel. The available volume can be changed by increasing the contact zone between the immiscible reagents where the reactions take place. The interfacial surface area is dependent on the intensity of mixing in the multiphase system. Interfacial area can also be increased by reducing the size of the dispersed phase droplets, such as by bubbling reagent methanol into the oil through a frit. Novel approaches to biodiesel production continue to be explored, particularly for lower grade and waste feedstocks, such as the direct extraction of fatty acid chains through use of a solvent such as an ionic liquid to pretreat esterification to the methyl ester [10]. Other work has examined methanol-based transesterification of waste cooking oil under quite mild conditions $\left(110^{\circ} \mathrm{C}\right.$ in $\left.2 \mathrm{~h}\right)$ in contact with tungsten oxide solid acid catalysts, giving yields of fatty acid methyl esters (FAME) that are close to the American Society of Testing and Materials (ASTM) standard for biodiesel [11]. The authors of that study, Komintarachat and Chuepeng, reported several advantages of working with a $\mathrm{WO}_{\mathrm{x}} /$ $\mathrm{Al}_{2} \mathrm{O}_{3}$ catalyst. Prior separation of free fatty acids, in their sample of waste cooking oil reported as $15 \%$, was not necessary to achieve high yields in a one step process. In addition, they found the catalyst has desirable properties for scale-up, being low cost, reusable, and less reactive than traditional homogeneous catalysts.

The choice of acid or base homogeneous catalysis depends on the concentration of free fatty acids (FFA) in the triglyceride feedstock. Virgin soybean oil has a low FFA content, $<4 \%$, and so can be converted to biodiesel by transesterification without an acid-catalyzed esterification pretreatment. However, oil that has been degraded by heat, such as waste oil, requires a two-step conversion. FFA produced during heating have to be esterified, otherwise they become saponified during transesterification. New processes are being developed to simplify the conversion of waste oil, such as the use of a supported heteropolyacid catalyst that simultaneously promotes both the esterification and transesterification processes [13]. 

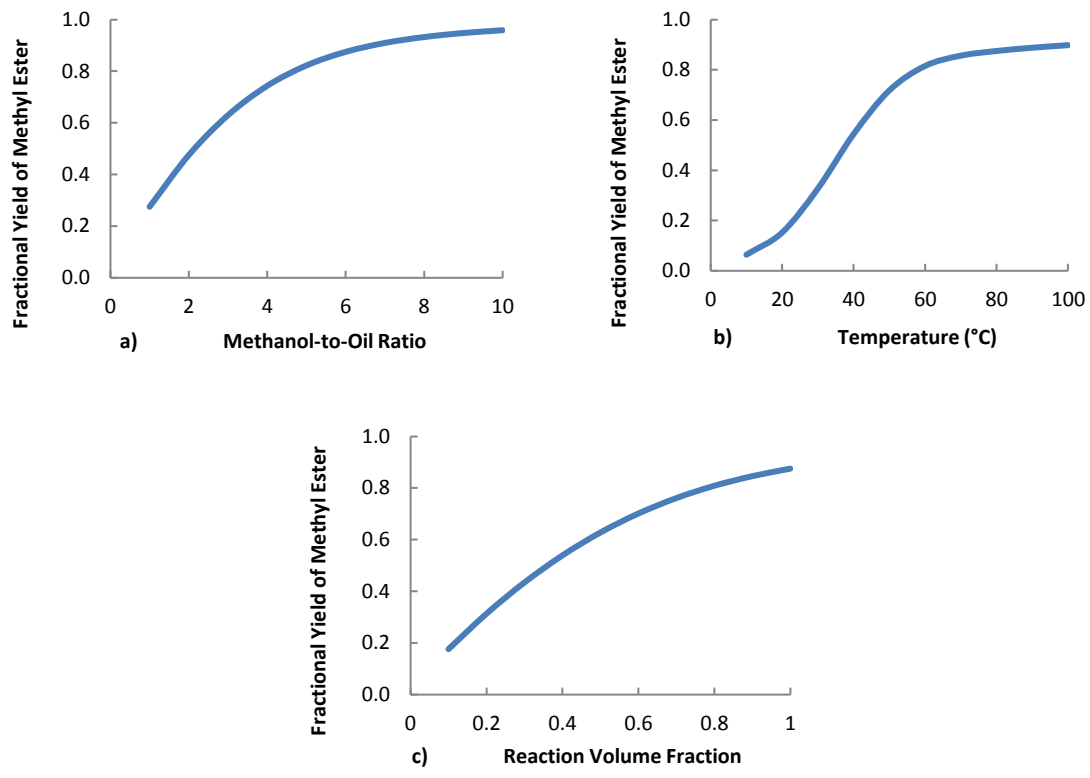

Figure 1. Results of parametric studies on methyl ester production in a continuous reactor showing (a) asymptotic approach to a maximum yield with methanol-to-oil molar ratio and (b) with reactor temperature. The dependence of yield on volume fraction simulated the effect of mixing in the reactor. These calculations were programmed in Mat$\mathrm{Lab}^{\circledast}[12]$, for nominal reaction conditions of $50^{\circ} \mathrm{C}, 7: 1$ methanol-to-oil molar ratio, and an effective reaction volume of $60 \%$ [9].

$$
\begin{aligned}
& \mathrm{C}_{3} \mathrm{H}_{5}\left(\mathrm{CO}_{2} \mathrm{R}^{1}\right)\left(\mathrm{CO}_{2} \mathrm{R}^{2}\right)\left(\mathrm{CO}_{2} \mathrm{R}^{3}\right)+\mathrm{CH}_{3} \mathrm{OH} \rightarrow \mathrm{CH}_{3} \mathrm{O}_{2} \mathrm{R}^{1}+\mathrm{C}_{3} \mathrm{H}_{5}(\mathrm{OH})\left(\mathrm{CO}_{2} \mathrm{R}^{2}\right)\left(\mathrm{CO}_{2} \mathrm{R}^{3}\right) \\
& \mathrm{C}_{3} \mathrm{H}_{5}(\mathrm{OH})\left(\mathrm{CO}_{2} \mathrm{R}^{2}\right)\left(\mathrm{CO}_{2} \mathrm{R}^{3}\right)+\mathrm{CH}_{3} \mathrm{OH} \rightarrow \mathrm{CH}_{3} \mathrm{O}_{2} \mathrm{R}^{2}+\mathrm{C}_{3} \mathrm{H}_{5}(\mathrm{OH})_{2}\left(\mathrm{CO}_{2} \mathrm{R}^{3}\right) \\
& \mathrm{C}_{3} \mathrm{H}_{5}(\mathrm{OH})_{2}\left(\mathrm{CO}_{2} \mathrm{R}^{3}\right)+\mathrm{CH}_{3} \mathrm{OH} \rightarrow \mathrm{CH}_{3} \mathrm{O}_{2} \mathrm{R}^{3}+\mathrm{C}_{3} \mathrm{H}_{8} \mathrm{O}_{3}
\end{aligned}
$$

\section{Triglyceride + 3 Methanoln3 Methyl Esters + Glycerine}

The chemical conversion to FAME produces a low viscosity, high-cetane number fuel that can be mixed directly with conventional diesel. The physical properties of diesel and biodiesel, or FAME, are compared in Table 1 [14]. The properties in the table are given for the liquid phase at $25^{\circ} \mathrm{C}$ and for vapor phase at $527^{\circ} \mathrm{C}$, corresponding to pre-ignition conditions in a compression ignition engine. Although similar in carbon chain length and cetane number, biodiesel differs from diesel significantly in its vapor pressure, liquid viscosity, and vapor diffusion coefficient. The properties of the biodiesel depend on the length and unsaturation of the fatty acid chains, Table 1 . Where the data are lacking for the soybean-derived methyl esters, the vapor phase properties for biodiesel have been replaced by those of methyl oleate. 


\begin{tabular}{|c|c|c|}
\hline Physical Property & Diesel* & Biodiesel* \\
\hline Density $\left[\mathrm{kg} \cdot \mathrm{m}^{-3}\right]$ & $762^{*}$ & $884^{*}$ \\
\hline vapor pressure $[\mathrm{Pa}]$ & $2.22^{*}$ & $6.10 \times 10^{-5}-1.18 \times 10^{-3 *}$ \\
\hline surface tension $\left[\mathrm{J} \cdot \mathrm{m}^{-2}\right]$ & $2.68 \times 10^{-2 *}$ & $2.49 \times 10^{-2 *}$ \\
\hline liquid viscosity [Pa·s] & $3.14 \times 10^{-3 *}$ & $9.10 \times 10^{-3 *}$ \\
\hline liquid thermal conductivity $\left[\mathrm{J} \cdot \mathrm{m}^{-1} \cdot \mathrm{s}^{-1} \cdot \mathrm{K}^{-1}\right]$ & $0.144^{*}$ & $0.100^{*}$ \\
\hline latent heat $\left[\mathrm{J} \cdot \mathrm{kg}^{-1}\right]$ & $3.60 \times 10^{5 *}$ & $3.38 \times 10^{5 * * *}$ \\
\hline liquid specific heat $\left[\mathrm{J} \cdot \mathrm{kg}^{-1} \cdot \mathrm{K}^{-1}\right]$ & $2.27 \times 10^{3 *}$ & $2.01 \times 10^{3 *}$ \\
\hline vapor specific heat $\left[\mathrm{kJ} \cdot \mathrm{mol}^{-1} \cdot \mathrm{K}^{-1}\right]$ & $0.643^{\#}$ & $0.848^{\#}$ \\
\hline vapor diffusion coefficient $\left[\mathrm{m}^{2} \cdot \mathrm{s}^{-1}\right]$ & $8.50 \times 10^{-6 \#}$ & $9.44 \times 10^{-7 \#}$ \\
\hline vapor viscosity $[\mathrm{Pa} \cdot \mathrm{s}]$ & $1.00 \times 10^{-5 \#}$ & $1.21 \times 10^{-5 * * \#}$ \\
\hline vapor thermal conductivity $\left[\mathrm{J} \cdot \mathrm{m}^{-1} \cdot \mathrm{S}^{-1} \cdot \mathrm{K}^{-1}\right]$ & $4.35 \times 10^{-2 \#}$ & $2.60 \times 10^{-2 \#}$ \\
\hline \multicolumn{3}{|l|}{ * Values at $25^{\circ} \mathrm{C}$ for liquids } \\
\hline \multicolumn{3}{|l|}{ \# Values at $527^{\circ} \mathrm{C}$ for vapors } \\
\hline
\end{tabular}

Table 1. Diesel $\left(\mathrm{C}_{14} \mathrm{H}_{30}\right)$ versus biodiesel properties at 25 or $527^{\circ} \mathrm{C}$

Although successfully blended up to 20 volume $\%$ for commercial and military use [16], methyl ester content in vehicle fuel is limited by a number of factors, including the performance in cold weather, the effect of oxygen content on engine components (particularly in the case of older engines), shelf-life and thermal stability [17], and higher $\mathrm{NO}_{x}$ emissions from engines that are not tuned to handle the higher temperature conditions of methyl ester combustion [18]. Results from simulations presented in Figures 2 and 3 show on a microscopic scale how the combustion of biodiesel can differ from diesel (represented as n-heptane in the engine simulations) in terms of temperature and emissions [15]. The development of engines that can accommodate biodiesel have focused on the effects of physical properties on spray parameters and droplet formation that will greatly affect the ignition conditions and combustion characteristics, Figures 2 and 3, and enhanced by early oxidation in the low temperature heat release phase of combustion, Figure 4 . Figure 4 shows the progression of the combustion of $20 \%$ biodiesel as a function of crank angle position, with $360^{\circ}$ corresponding to top-dead-center. The key radicals in the low temperature heat release portion of the cycle include $\mathrm{OH} \bullet$ and $\mathrm{HO}_{2} \bullet$, but $\mathrm{OH} \bullet$ dominates after the main ignition event. 


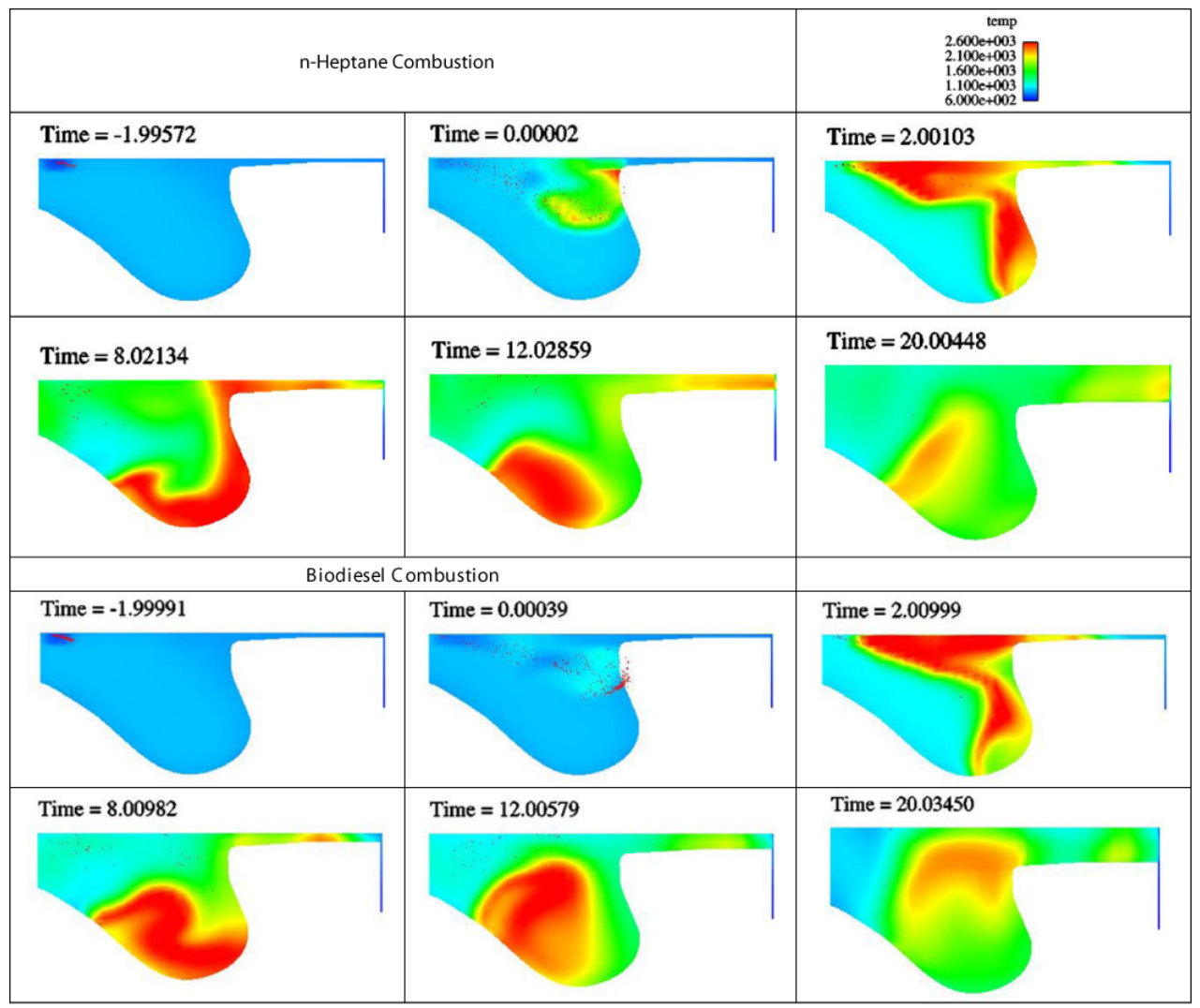

Figure 2. Predicted differences in the temperature in $\mathrm{n}$-heptane and biodiesel combustion after injection into the cylinder. The $n$-heptane, representing diesel fuel, shows combustion occurring very rapidly after injection, $2 \times 10^{-8} \mathrm{~s}$. The biodiesel, while slower to vaporize and ignite, shows a higher temperature at $12 \mathrm{~ms}$ after injection. The simulations were done assuming a cycle of $2000 \mathrm{Rev} / \mathrm{min}$. The temperature key in the upper right is given in degrees K. Reprinted with permission from SAE paper 2008-01-1378 Copyright (c) 2008 SAE International [15].

These factors have led to interest in synthesizing a hydrocarbon fuel starting with methyl esters, a so-called "green diesel" that will maintain the high cetane number of biodiesel, but will achieve better performance in an automobile: through enhanced mixing, injection, and combustion; reduced downstream issues such as $\mathrm{NO}_{x}$ emissions; and better upstream handling associated with fuel manufacture and distribution. Bunting and colleagues have reviewed the development of fungible and compatible biofuels [20]. That report considers a wide variety of products, from ethanol to pyrolysis oils as well as soy-derived biodiesel. Concerns that arise when developing alternative fuels include refining, blending, and distribution, regulatory barriers, verification of performance, and changes in operating practices throughout the distribution system. In this chapter, we focus on the chemistry of the fuel. 


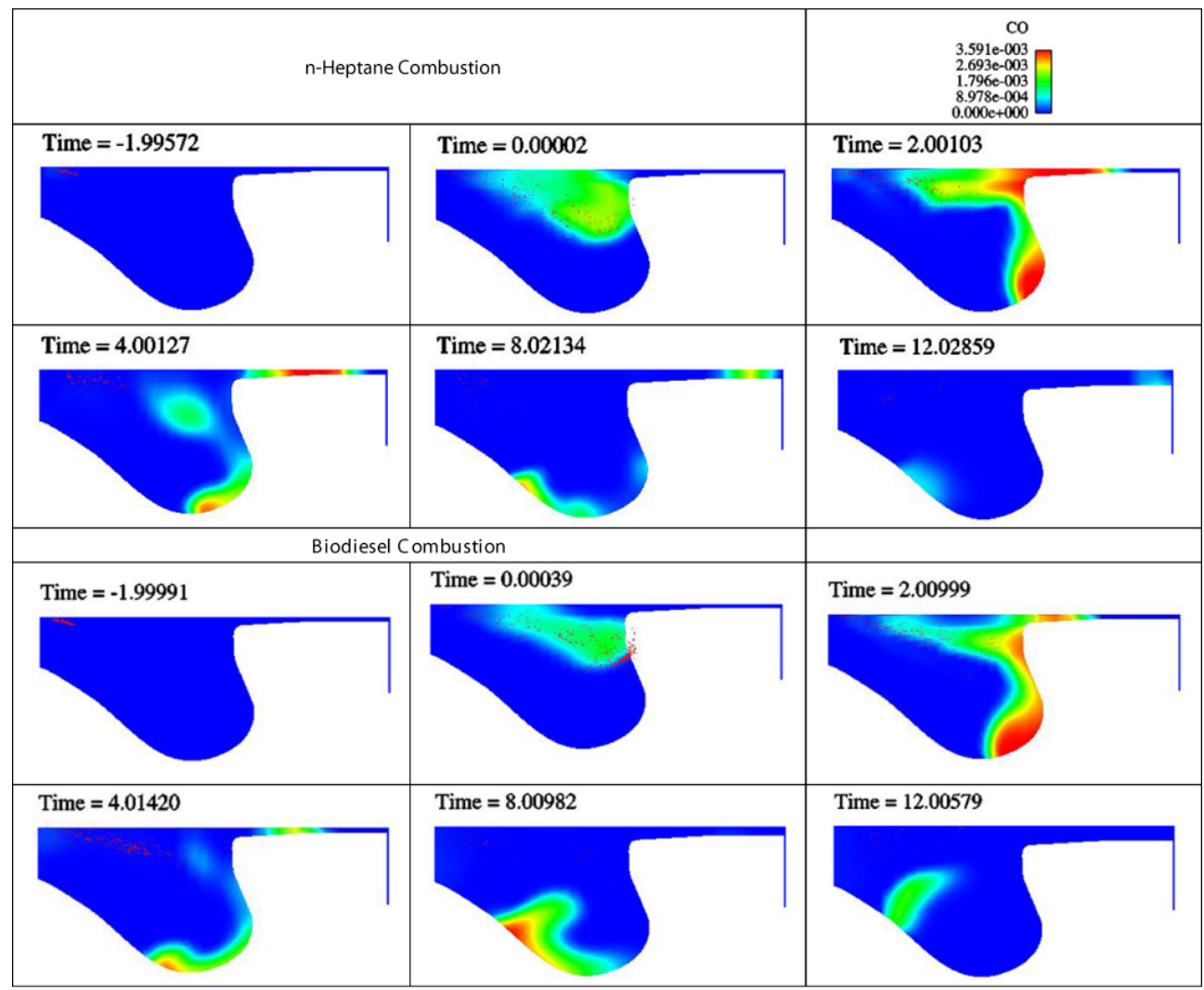

Figure 3. Predicted differences in the $\mathrm{CO}$ concentration in $\mathrm{n}$-heptane and biodiesel combustion after injection into the cylinder. As with the temperature profiles, the production of CO from biodiesel lagged that from $\mathrm{n}$-heptane during the event. However, the final concentration of $\mathrm{CO}$ was higher for biodiesel than for $\mathrm{n}$-heptane. The CO concentration key in the upper right is given in mole fraction. Reprinted with permission from SAE paper 2008-01-1378 Copyright (c) 2008 SAE International [15].

Unsaturated methyl esters have more affinity for water and contaminants than does hexadecane, a typical component of diesel fuel. Water affinity is often expressed in the form of the octanol-water distribution coefficient or $\mathrm{K}_{\mathrm{ow}}$, with lower values of $\mathrm{K}_{\mathrm{ow}}$ indicating more hydrophilic compounds, $\mathrm{K}_{\mathrm{ow}}=$ moles(octanol)/moles(water). $\mathrm{K}_{\mathrm{ow}}$ values for a few select components of fossil-based diesel [21] and long chain methyl esters typical of those derived from soy oil [22] are presented in Table 2. Water can be problematic in fuel distribution systems which are made of low carbon or low grade stainless steel, but water can be gravity separated when the fuel is held in storage vessels. Separation is less likely to occur with oxygenated fuels, particularly those that have degraded to shorter chain components through autooxidation. Because of the issues with materials compatibility, potential contamination of pipe- 
lines by residues, and high viscosity at low temperatures, biodiesel must be added to standard diesel fuel at a terminal loading facility, where the fuel is mixed and then loaded onto trucks for distribution. However, mixing at a distribution terminal affords less quality control than at a refinery, with the latter having the ability for online testing of properties and composition, followed by adjustment to meet ASTM specifications if necessary [23].

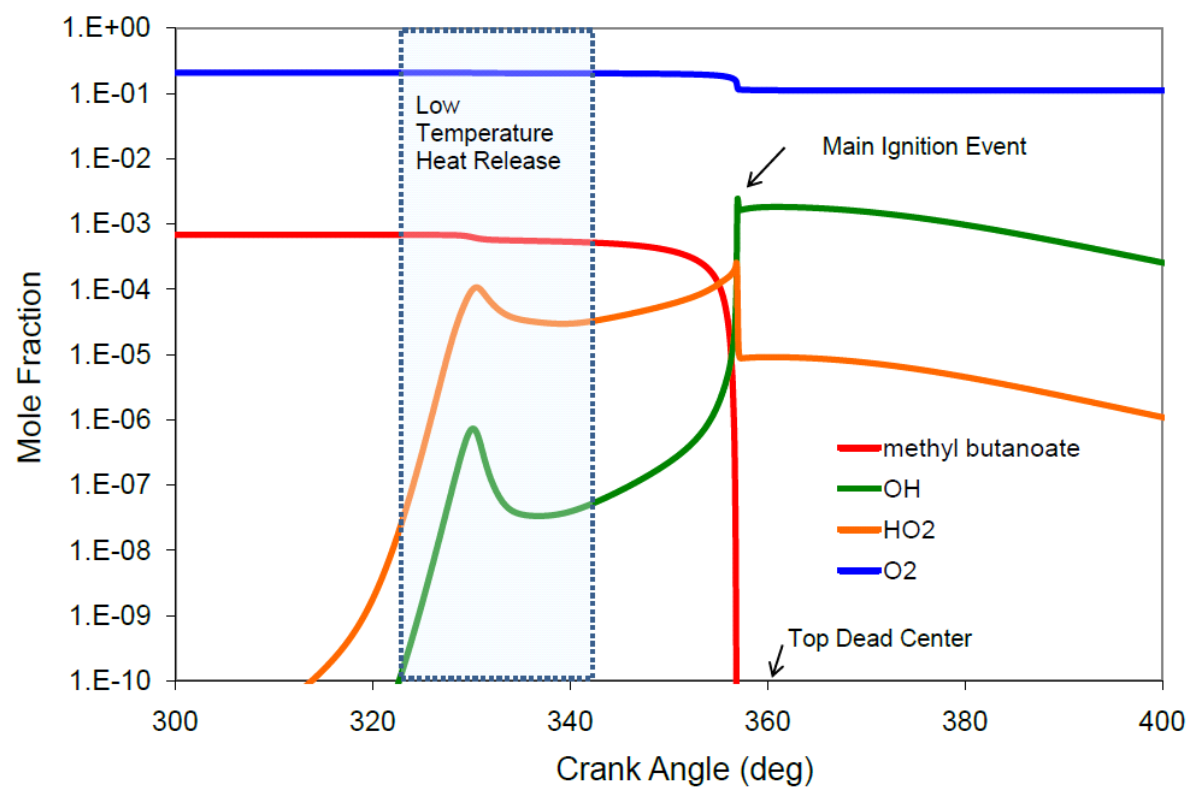

Figure 4. Combustion of a $20 \%$ blend of methyl butanoate (simulating biodiesel) and $n$-heptane (simulating petroleum diesel) showing the importance of reactive species during different times of the cycle [19].

Biodiesel derived from soybean oil comprises long fatty acid chains, C16-C18, with a high cetane number, and a high degree of unsaturation, $84-87 \%$, for better cold flow properties (reduced viscosity) relative to other plant-based methyl esters. However, the unsaturation can also lead to issues with shelf life and thermal stability [28] in comparison with more hydrogenated oils such as palm oil. The process of oxidation and its effects on the properties of biodiesel has been studied using chemical and thermal analysis by Tan and colleagues [29], and reviewed by Mushbrush [17] and Knothe [30]. Oxidation of the double bonds can occur through an autocatalytic mechanism simplistically depicted below, Reaction (2), initiated by hydrogen abstraction from an unsaturated carbon atom. The greater the unsaturation, the more stable the allylic radical, $R_{n} \bullet$, thus a precursor mono-unsaturated FFA has greater stability that the doubly- and triply-unsaturated chains. Once formed, the radical can combine with $\mathrm{O}_{2}$, allowing formation of a secondary intermediate in the chain, a reactive hydroperoxide [31, 32], Reaction (3). Light increases the rate of decomposition, because photosensitization allows a direct reaction between the $\mathrm{O}_{2}$ and the 
carbon-carbon double bond offering another pathway to oxidation. The hydroperoxides, once formed, can convert to a variety of products, cyclized five and six membered rings, malonaldehyde or $\mathrm{C}_{3} \mathrm{O}_{2} \mathrm{H}_{4}$, hydroxy and epoxy esters, and allylic hydroxyl- and ketone compounds, among other oxygenated derivatives. Cleavage reactions form reactive radicals, continuing the process to produce volatile compounds such as carbonyls, alcohols, esters, and short chain hydrocarbons, Reactions (4a and b), some of which react to form furans, aldehydes, ketones, lactones, alkynes, and aromatics [33]. Because of an associated increase in viscosity and acid number, these oxidation products are generally undesirable in a combustion engine [34].

\begin{tabular}{|c|c|c|}
\hline & $\log \mathrm{K}_{\mathrm{ow}}$ & $\begin{array}{l}\text { water solubility (mg/ } \\
\text { L)at } 25^{\circ} \mathrm{C}\end{array}$ \\
\hline \multicolumn{3}{|c|}{ Biodiesel Components } \\
\hline $\begin{array}{l}\text { methylpalmitate, C16:0 } \\
(10-12 \%) \\
\text { (hexadecanoic acid, methyl ester) }\end{array}$ & 7.38 & $4.00 \times 10^{-3}$ \\
\hline $\begin{array}{l}\text { methyl stearate, C18:0 (3-4\%) } \\
\text { (octadecanoic acid, methyl ester) }\end{array}$ & 8.35 & $3.01 \times 10^{-3}$ \\
\hline $\begin{array}{l}\text { methyloleate, C18:1 (23-25\%) } \\
\text { (octadecenoic acid, methyl ester) }\end{array}$ & 7.45 & $3.68 \times 10^{-3}$ \\
\hline $\begin{array}{l}\text { methyllinolate, C18:2 (53-56\%) } \\
\text { (octadecadienoic acid, methyl ester) }\end{array}$ & 6.82 & $2.10 \times 10^{-2}$ \\
\hline $\begin{array}{l}\text { methyllinolenate, C18:3 (6-8\%) } \\
\text { (octadecatrienoic acid, methylester) }\end{array}$ & 6.29 & $9.18 \times 10^{-2}$ \\
\hline Diesel \#2 Components & & \\
\hline $\begin{array}{l}\text { Monoaromatics and small cyclic compounds } \\
(10.0 \%)\end{array}$ & $\begin{array}{c}2-5 \\
\text { Hexylbenzene is } 5.52\end{array}$ & 1.02 \\
\hline cycloparaffins (34.0\%) & $\begin{array}{c}3-5 \\
\text { Cyclohexane is } 3.44\end{array}$ & $55[27]$ \\
\hline Naphthalenes and PAH (14.7\%) & $\begin{array}{c}3-5 \\
\text { Naphthalene is } 3.3\end{array}$ & 30 \\
\hline n- and i-paraffins (41.3\%) & $\begin{array}{l}\text { 3.3-7.06 for short chain } \mathrm{HC}[21] \\
8.2 \text { for } \mathrm{C}_{16} \mathrm{H}_{34}\end{array}$ & $9 \times 10^{-4}$ \\
\hline
\end{tabular}

Table 2. Hydrophobicity expressed as octanol-water partition coefficients [24, 25] for organic derivatives of petroleum and biodiesel [26] 


$$
\begin{aligned}
& \mathrm{R}_{\mathrm{n}}-\mathrm{H} \rightarrow \mathrm{R}_{\mathrm{n}} \cdot+\mathrm{H} \cdot \\
& \mathrm{R}_{\mathrm{n}} \cdot+\mathrm{O}_{2} \rightarrow \mathrm{R}_{\mathrm{n}} \mathrm{OO} \\
& \mathrm{R}_{\mathrm{n}} \mathrm{OO}+\mathrm{R}_{\mathrm{n}^{\prime}}-\mathrm{H} \rightarrow \mathrm{R}_{\mathrm{n}} \mathrm{OO}-\mathrm{H}+\mathrm{R}_{\mathrm{n}^{\prime}} \\
& \mathrm{R}_{\mathrm{n}}-\mathrm{C}=\mathrm{C}-\mathrm{R}_{\mathrm{n}^{\prime}}+2 \mathrm{O}_{2} \rightarrow \mathrm{R}_{\mathrm{n}}-\mathrm{C}(\mathrm{OOH})-\mathrm{C}=\mathrm{C}-\mathrm{R}_{\mathrm{n}^{\prime}-1}+\mathrm{R}_{\mathrm{n}-1}-\mathrm{C}=\mathrm{C}-\mathrm{C}(\mathrm{OOH})-\mathrm{R}_{\mathrm{n}^{\prime}} \\
& \mathrm{R}_{\mathrm{n}}-\mathrm{CH}=\mathrm{CH}-\mathrm{C}(\mathrm{O} \cdot) \mathrm{H}-\mathrm{R}_{\mathrm{n}^{\prime}} \rightarrow \mathrm{R}_{\mathrm{n}^{\prime}}-\mathrm{CHO}+\mathrm{R}_{\mathrm{n}}-\mathrm{CH}=\mathrm{CH} \cdot(\mathrm{a}) \\
& \mathrm{R}_{\mathrm{n}}-\mathrm{CH}=\mathrm{CH}-\mathrm{C}(\mathrm{O} \cdot) \mathrm{H}-\mathrm{R}_{\mathrm{n}^{\prime}} \rightarrow \mathrm{R}_{\mathrm{n}}-\mathrm{CH}=\mathrm{CH}-\mathrm{CHO}+\mathrm{R}_{\mathrm{n}^{\prime}} \cdot(\mathrm{b})
\end{aligned}
$$

Besides light and heat, oxidative stability is also greatly influenced by the choice of storage tank materials and the presence of minor components or contaminants in the mixture. Hence, deterioration can be slowed by the use of additives in the fuel. Commonly used antioxidants include phenol derived compounds such as tert-butyl hydroquinone (TBHQ) [35], butylatedhydroxytoluene (BHT), butylatedhydroxanisole (BHA), and propyl gallate. Effective additive concentrations of $1000 \mathrm{mg} \mathrm{kg}^{-1}$ (1000 ppm) do not appear to affect combustion or physical properties [36], but are sufficient to increase the induction period for autooxidation by binding with the peroxy radicals as shown created in Reaction (2) [37]. Phosphorylated antioxidants, including phosphites, phosphonites and phosphines [38], either hinder hydrogen atom extraction or promote the decomposition of hydroperoxides [39], Reaction (5). They are often used in combination with the phenolic antioxidants for additional efficacy. Organosulfites can also be used to stabilize methyl esters, as they react with hydroperoxides to form sulfates [40].These compounds would be less than desirable as fuel additives; however, as the non-radical decomposition is catalyzed by the presence of acid, and ultimate products include $\mathrm{SO}_{x}$ and acids $\mathrm{H}_{2} \mathrm{SO}_{3}$ and $\mathrm{H}_{2} \mathrm{SO}_{4}$.

$$
\mathrm{R}_{\mathrm{n}} \mathrm{OO} \cdot \mathrm{A}-\mathrm{H} \leftrightarrow \mathrm{R}_{\mathrm{n}} \mathrm{OO}-\mathrm{H}+\mathrm{A} \cdot
$$

\section{Chemical conversions}

For soybean oil and soybean-derived feedstocks to be used as drop-in replacements for petroleum derived products, deoxygenation processing has to be undertaken. Depending on the desired products, this can involve a number a steps, listed below. Not all of the steps are needed for each product. In general, the desire is to shift increase the carbon-to-oxygen ratio to be closer to that of petroleum, and reduce the carbon to hydrogen ratio, as depicted in Figure 5, plotted with data collected by Choudhary [41]. The various catalysts used to achieve the deoxygenation of triglycerides has been reviewed in a number of publications, for instance by Morgan [42].

i. Hydrogenation (saturation of double bonds)[43] 
ii. Thermal cracking - heating in an inert atmosphere without addition of $\mathrm{H}_{2}$

iii. Acid- or base-catalyzed cracking over metal oxides or zeolites [44]

iv. Hydrodeoxygenation ( $\mathrm{HDO}$ removal of $\mathrm{O}$ as $\mathrm{H}_{2} \mathrm{O}$ ) - usually at higher $\mathrm{H}_{2}$ pressure and lower temperatures than the cracking processes. The catalyst has transition metal + heteroatom $\left(\mathrm{S}\right.$ or $\mathrm{N}$ ) like $\mathrm{NiMo} / \mathrm{Al}_{2} \mathrm{O}_{3}$ or $\mathrm{CoMo} / \mathrm{Al}_{2} \mathrm{O}_{3}$. Non-sulfided forms have also been studied to a lesser extent, $\mathrm{Ni} / \mathrm{Al}_{2} \mathrm{O}_{3}$ or $\mathrm{Ni} / \mathrm{SiO}_{2}$.

v. Decarboxylation (remove $\mathrm{O}$ as $\mathrm{CO}_{2}$ ) - more $\mathrm{H}_{2}$ efficient than $\mathrm{HDO}$, unless product $\mathrm{CO}_{2}$ becomes methanized. Often uses supported platinum catalysts in a batch reaction, for example: $\mathrm{Pt} / \mathrm{Al}_{2} \mathrm{O}_{3}$ or $\mathrm{Pd} / \mathrm{C}, 270-360^{\circ} \mathrm{C}, 17-40$ bar $\mathrm{H}_{2}$.

vi. Decarbonylation or removal of oxygen as $\mathrm{CO}$ - same catalysts as decarboxylation

vii. Removal of other heteroatoms (S, N, P, metals) - especially from used cooking oil or if sulfur and nitrogen compounds have been added in earlier processes to maintain the catalyst activity.

viii. Various side reactions including: hydrocracking, water-gas shift, methanization, cyclization, and aromatization

ix. Isomerization [45], often deliberately designed to produce better fuel characteristics, such as cold flow behavior. For example, linear paraffins, $n=16-18$, freeze at $18-28^{\circ} \mathrm{C}$, while iso-paraffins of the same carbon number freeze at -11 to $3^{\circ} \mathrm{C}$

x. Co-processing of soybean oil with diesel fuels in an oil refinery by fluidized catalytic cracking (FCC) - achieves isomerization as well as separations. May get inhibition of deoxygenation because of $S$ groups in the diesel fuel components and vice versa.

\section{Oil feedstocksfor hydrocarbon fuels}

Deoxygenation drives the overall process for converting soybean oil into hydrocarbons. Processing requirements will be similar for both fuels and chemical feedstocks if the product from deoxygenation can be introduced as a feed in a petrochemical refinery where it will undergo further reactions and separation. If the goal is to only make hydrocarbon fuels; however, separations may not be as important after deoxygenation as they would be for isolating particular building block chemicals. Conversion in a smaller scale independent biorefinery may be feasible, solving the issue of the distributed production of soybeans. The drawback to this scheme is that if the fuels are to be introduced directly into the distribution system, issues related to quality control of the product may become siginificant. In this case, processing will have to account for the variability of bio-based feedstocks, even within a particular crop. Hence, for fuel production at a distributed processing facility, the goals would include achieving sufficient deoxygenation to allow incorporation upstream of the distribution point, enabling pipeline transportation, and providing reliability and quality control. 


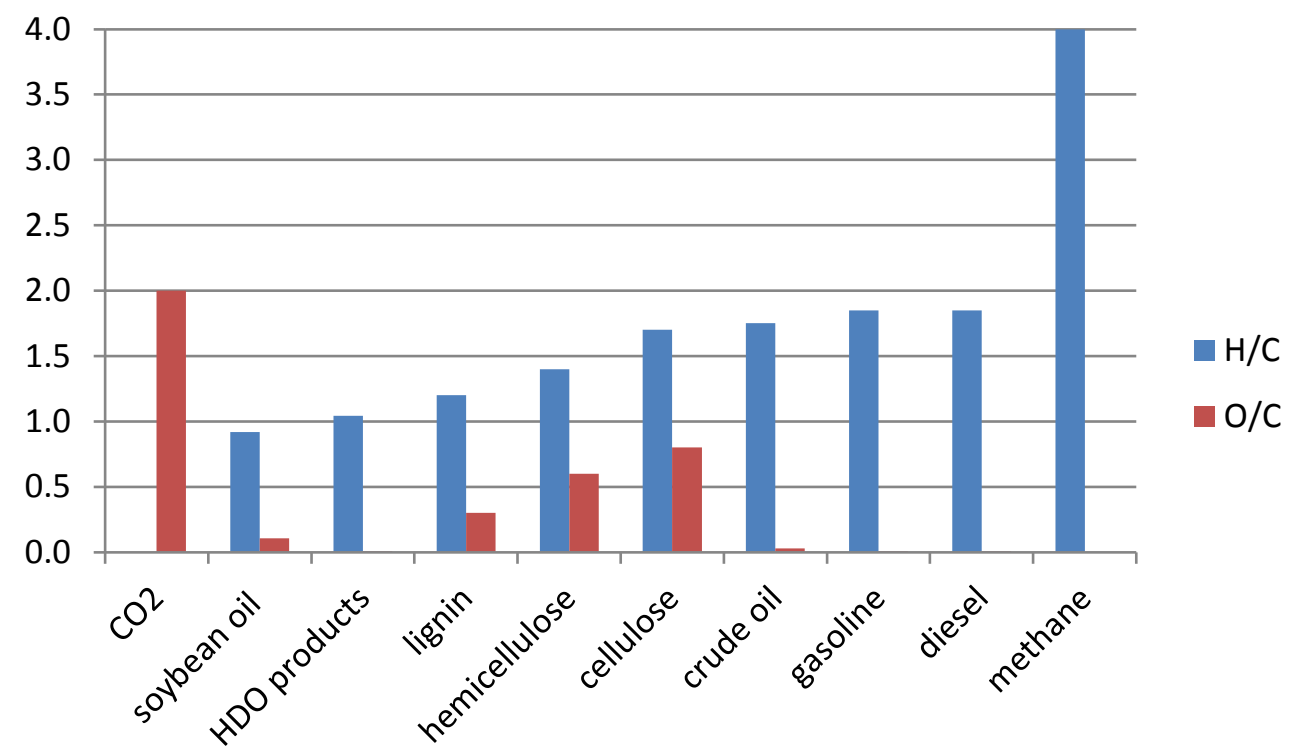

Figure 5. Progression in $\mathrm{H} / \mathrm{C}$ mole ratio and $\mathrm{O} / \mathrm{C}$ mole ratio for different sources of organic materials

Thermal cracking has the advantage of not requiring hydrogen for processing. Uncatalyzed thermal cracking has been used to convert soybean oil to hydrocarbons, holding the oil at $430-440^{\circ} \mathrm{C}$ under vacuum for over one hour [46]. Not including the free fatty acid byproducts, more than half of the products comprised linear alkanes (51\%). Other significant hydrocarbon products were identified by gas chromatography - mass spectroscopy as cycloalkanes $(11 \%)$, alkenes $(20 \%)$, cycloalkenes $(5 \%)$, aromatics $(8 \%)$, and polyaromatic hydrocarbons or PAH (5\%). The authors contend that the rings, both saturated and aromatic, came from cyclization of the fatty acid chains rather than from a Diels Alder addition. The latter is usually considered the mechanism for ring formation from olefins, but in the case of the soybean oil conversion, the precursor dienes were not observed. The FFA also became decarboxylated, releasing hydrogen for saturation of double bonds, and producing byproducts $\mathrm{CO}_{2}$ and $\mathrm{CO}$. The significant fraction of $\mathrm{PAH}$ could be problematic for direct combustion of the resulting fuel, as these compounds can survive conditions through the combustion pathway in the engine and be emitted into the atmosphere. However, pretreatment, to reduce the acid number and separation of the FFA, would allow this feedstock to be transported to a refinery for further processing. In thermal cracking, the most important variables governing product distribution include the temperature followed by the residence time [46-48]. Other literature has described investigations of catalysts that have shown promise for thermal cracking, including supported $\mathrm{Ni}, \mathrm{Pt}$ or $\mathrm{Pd}$ on carbon. In particular, Morgan and coworkers have discovered a Ni/C catalyst and demonstrated a $92 \%$ conversion of soybean-derived triglyceride at $400^{\circ} \mathrm{C}$, with a $70 \%$ yield in liquid form [42]. 
Biogas oil, which is a mixture of normal and isoparaffins having boiling points close to that of diesel, may be made from selective hydrotreating of natural triglycerides. Although some research on thermal cracking has suggested that introduction of hydrogen is not necessary [47], the HDO process allows the conversion to be carried out at lower temperatures, with fewer issues related to byproduct char and gas formation. Hydrodeoxygenation has also received much attention in the literature because this process shows promise to operate with less hydrogen than needed for hydrogenation [41]. HDO, in fact, involves a series of hydogenolysis and hydrogenation steps and is analogous to hydrodesulfurization of petroleum. Catalysts have already been developed for hydroprocessing of heavy oils. HDO investigations have been carried out on a number of seed oils, including soybean oil. For instance, rapeseed oil was deoxygenated at $260-280^{\circ} \mathrm{C}$ under $3.5 \mathrm{MPa} \mathrm{H}_{2}$. The rate of reaction ranged over $0.25-4 \mathrm{~h}^{-1}$ when tested with a number of different catalysts, in order of performance: $\mathrm{Ni}$ $\mathrm{Mo} / \mathrm{Al}_{2} \mathrm{O}_{3}>\mathrm{Mo} / \mathrm{Al}_{2} \mathrm{O}_{3}>\mathrm{Ni} / \mathrm{Al}_{2} \mathrm{O}_{3}$ [49]. HDO of sunflower oil was performed in DMSO, with a $\mathrm{NiMo} / \mathrm{Al}_{2} \mathrm{O}_{3} / \mathrm{F}$ catalyst, in a bench-scale continuous operation at high pressure. The oil hydrocracking entailed combined processes, including olefinic double bond saturation, oxygen removal, and isomerization [50], to give a conversion of $90 \%$. HDO of sunflower oil $\left(310-360^{\circ} \mathrm{C}, 2.0 \mathrm{MPa}\right)$ on a $\mathrm{Pd} / \mathrm{SAPO}-31$ catalyst gave excellent conversion to $\mathrm{C} 17$ and $\mathrm{C} 18$ straight chain and branched alkanes. However, the catalyst became fouled after a few hours [51]. Mixtures of sunflower oil and gas oil have been hydroprocessed over a sulfided catalyst, $\mathrm{NiO}(3 \%)-\mathrm{MoO}_{3}(12 \%)-\gamma-\mathrm{Al}_{2} \mathrm{O}_{3}$ incorporating 0,15 or $30 \mathrm{wt}$. $\%$ zeolite beta (BEA). The reaction took place at conditions of $330^{\circ} \mathrm{C}, 60$ bar, at a weight hourly space velocity (WHSV) of $2 \mathrm{~h}^{-1}$, giving $100 \%$ conversion into hydrocarbons. The distribution arising from cracking giving the relative fractions of liquids/gases/and char was not discussed in the paper [52].

Hydrocracking has also been scaled up from the laboratory bench. A larger scale test of hydrocracking of fresh sunflower oil and used cooking oil was carried out by Bezergianni and colleagues [6]. The cracking process was carried out over a number of days until steady state was reached, and then an analysis was performed on the products. A presulfided commercial HDO catalyst was used, with sulfur in the form of dimethyldisulfide and nitrogen as tetra-butyl amine added to maintain the activity. The liquid hourly space velocity (LHSV) was $1.5 \mathrm{~h}^{-1}$ and the $\mathrm{H}_{2}$-to-liquid ratio was $1098 \mathrm{Nm}^{3} / \mathrm{m}^{3}$ (at $14 \mathrm{MPa}$ ). The difference in performance between the conversion of used and new oil was very small, with high yields of product in the diesel fuel boiling point range (70-80\%). Less cracking to small molecules was observed at lower temps, i.e., $350^{\circ} \mathrm{C}$, than $390^{\circ} \mathrm{C}$, which is desirable for fuel manufacture.

The effect of sulfur on hydrodeoxygenation is of interest because it relates to the performance in an oil refinery with hydrodesulfurization (HDS) as well as HDO processing. Experiments over $\mathrm{Pt} / \mathrm{H}-\mathrm{Y}, \mathrm{Pt} / \mathrm{H}-\mathrm{ZSM}-5$, and sulfidedNiMo $/ \gamma-\mathrm{Al}_{2} \mathrm{O}_{3}$ have been carried out in a batch reactor over a temperature range of $300-400^{\circ} \mathrm{C}$ and initial hydrogen pressures from 5 to 11 $\mathrm{MPa}$. The reaction time was limited to $3 \mathrm{~h}$ [53]. Investigation of the performance of $\mathrm{CoMo} /$ $\mathrm{Al}_{2} \mathrm{O}_{3}$ at different sulfur levels $\left(1 \%\right.$ to $\left.<10 \mathrm{mg} \mathrm{kg}^{-1}\right)$ and its effect on the $\mathrm{HDO}$ of sunflower oil were done under the following conditions: $300-380^{\circ} \mathrm{C}, 20-80 \mathrm{bar}, 1-3 \mathrm{~h}^{-1}$, and $\mathrm{H}_{2} / \mathrm{oil} \mathrm{vol}^{-}$ ume $200-800 \mathrm{Nm}^{3} / \mathrm{m}^{3}$ [54]. Up to $75 \%$ of the target product C18-paraffins were made at the highest temps and lowest LHSV. At higher $\mathrm{H}_{2}$ pressures, more hydrocracking occurred, 
forming light gases such as propane. Adding presulfided catalysts got better yields (5-8\%) under less severe conditions. But the addition of sulfur can produce $\mathrm{H}_{2} \mathrm{~S}$, which needs to be removed from product and recycled. Sulfur can react to form mercaptans, which are corrosive, adding cost and complexity to the process. $\mathrm{H}_{2} \mathrm{~S}$ has been found not to prevent catalyst deactivation as was anticipated. The effect of sulfur has also been investigated for the HDO of aliphatic ester model compounds [55].

Hydrogenation and deoxygenation to n-paraffins followed by isomerization is expensive and complicated, but now is performed on an industrial scale [41]. A Finnish company, Neste Oil, has built and operated three NexBTL plants around the world, in Singapore, Rotterdam, and Porvoo in 2009, to convert 190,000 t/a of C12-C16 triglycerides, fatty acid esters, and fatty acids to green diesel. The conversion involves hydrotreatment followed by isomerization to produce green diesel and is described in a Neste patent [56]. The Neste Singapore plant is rated at $800,000 \mathrm{t} / \mathrm{a}$ of palm oil, used oil and waste animal fat. A plant in Rotterdam started production in mid 2011 that uses a variety of feedstocks.

Another company, UOP/ENI S.p.A., has a process to produce green diesel that involves a number of catalytic steps to achieve deoxygenation and conversion to branched hydrocarbons. The process, based on hydrodeoxygenation, produces fuel that can be blended directly with petroleum, or added to an input stream in an oil refinery [56]. Emerald Biofuels plans to build a $85 \times 10^{6}$ gallon production facility based on the UOP technology (licensed by Honeywell) at a Dow Chemical site in Plaquemine, LA. Dynamic Fuels is already in production $\left(75 \times 10^{6} \mathrm{gal}\right)$ and Diamond Green Diesel $\left(137 \times 10^{6} \mathrm{gal}\right)$ also has a plant under construction at the mouth of the Mississippi, to take advantage of the proximity to shipping and petroleum refineries. The existing capacity, along with the operating Neste plants, currently produces $600 \times 10^{6} \mathrm{gal} / \mathrm{a}$ [57].

ExxonMobile is building a hydrotreating plant in Singapore to deliver bio-derived low sulfur diesel of up to $16 \times 10^{6} \mathrm{~L} / \mathrm{d}$, and has similar plants planned for Baytown and Baton Rouge, LA, in the USA [58].Other planned green biodiesel projects include sites at Norco LA ( Darling International, Diamond Green Diesel, LLC, and Valero Energy Corp) to produce $137 \times 10^{6} \mathrm{gal} / \mathrm{a}$ from waste oil, and animal fats. KiOR plans construction of a plant to produce refinery intermediates in Columbus MS. Joule Unlimited will be constructing a biofuels

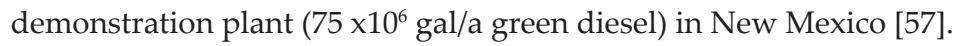

Although hydrodeoxygenation is fairly mature, with industrial-scale production, technical problems remain that would benefit from further research. Minimization of hydrogen used in the conversion of biomass must happen to make the process economically viable [59]. A large fraction of the products from hydrodeoxygenation are linear paraffinic hydrocarbons, which tend to form waxes that can cause cold flow problems. Research into isomerization reactions and selection of catalysts to promote branched alkanes would be beneficial. In the case of soybean oil, however, thermal cracking has produced a preponderance of aromatic compounds, suggesting that mixing of fractions produced through different pathways may give rise to a fungible fuel. A third area of interest is the effect of acylglycerides and HDO products on catalysts that are used in oil refinering, especially if the bio derivatives are to be introduced into the feed stream along with petroleum. In particular, there is a concern that 
the acylglycerides may affect the performance of catalysts such as CoMo, used in hydrodesulfurization [41].

The activities undertaken by industry show that the underlying drivers for biofuel production low sulfur requirements in diesel, low net $\mathrm{CO}_{2}$ emission during production and use, and potentially disruptive oil supply disruptions are pushing major companies to make investments in this area. Although the feedstock streams for biorefineries are not specific to soybean oil, the engineering efforts contribute to the general knowledge of producing green diesel from a variety of sources. Yet, the industry is sensitive to changes in feedstock and oil prices, and smaller initiatives have lost traction during changes in the market, particularly during the last few years. Currently, green diesel remains a niche player in the larger petroleum refining industry.

\section{Oil feedstocksfor materials}

Soybean plants have been used to fabricate a variety of materials and products. Soybean derived materials have been used in the development of bio-based fibers and yarns [60]. In particular soybean protein fiber has been identified having potential uses [61] in the manufacturing of fabrics. Materials production may not require the degree of chemical conversion and breakdown of the triglyceride that hydrocarbon production requires, but modification is still required to give the desired properties. For instance, soybean protein separated through precipitation after the oil has been removed from the seed requires further processing to crosslink the derived fibers and reduce brittleness and degradation [62,63]. Soybean straw, available after harvesting of the beans, can be converted to technical fibers through alkali processing. The straw-derived fibers have a higher lignin content than cotton or linen, but after processing the cellulose content is comparable to these other agricultural sources, and could represent a bioresource estimated to be 55 million tons derived from 220 million tons of straw [64]. Soybean fiber left over from oil and protein extraction can be converted to ethanol through a two-step process: (i) pretreatment with aqueous ammonia to remove lignin (by $74 \%$ after 12 hours), and (ii) simultaneous saccharification and fermentation, giving $0.25 \mathrm{~g}$ ethanol per gram of fiber [65]. The straw can also be converted to a bio-oil through fast pyrolysis [66].

\section{Oil feedstocksfor chemicals}

Soybean oil can be used to manufacture a number of different compounds including surfactants, fuel additives, detergents, polymers such as polyurethanes [67], and adhesives [68]. Polymer production from biomaterials has recently been reviewed by Lligadas and colleagues [69]. Fatty acids can be converted to a polyurethane through a di-isocyanate intermediate [70].Resin alternatives have been prepared from a number of different plant-derived materials, including soybean oil. To achieve the physical properties required for a thermo- 
plastic polymer, that is having sufficient rigidity and tensile strength to be used in fabrication, soybean oil derived resins must be crosslinked via epoxidation (introduction of epoxy groups into double bonds on the fatty acid chains) or mixed with petroleum-based materials. Good results obtained without incorporating conventional polymers used a combination of epoxidized soybean oil and an anhydrided soyate. The linking process was catalyzed with hexamethylenediamine, and gave a fiber with a tensile strength of $>10 \mathrm{MPa}$ [71]. Adhesives made of renewable polymers have been made from mixing of dimeric fatty acids and diols with maleic-anhydrided soybean triglycerides. The gel is formed from cross linking of the esters and extending the fatty acid chains within the structure [72]. Hybrid coatings have been prepared from mixing blown soybean oil and sol-gel precursors (titanium and zirconium peroxides) to improve properties such as tensile strength, adhesion, flexibility, hardness and impact resistance [73].

The conversion of plant-based acylglycerides to nitrogen containing compounds has been reviewed by Biswas and colleagues [74].Properties of various products from palmitic acid have been predicted based on a combinatorial approach, and then linked to an optimization routine to select the product of choice based on predefined criteria (lubricity, critical micelle concentration, or hydrophilic-lipophilic balance) [75]. The authors, Carmada and Sunderesa$\mathrm{ni}$, wanted to refocus the synthesis paradigm. They developed a method to choose a chemical structure that would give thermophysical properties optimized to a particular application. The structure then determined which synthetic method would be needed to produce the desired end product.

\section{Methyl ester feedstocks for chemicals}

Methyl esters derived from soybean oil can also be used as starting materials for the production of hydrocarbons for fuels or chemical feedstocks. Various catalytic pathways from oxygenated precursor to hydrocarbons include: pyrolysis [76], deoxygenation and hydrogenation [77, 78], and hydrotreatment [79]. The focus of many of these studies has been production of fuels that are miscible or fungible with petroleum products, e.g., the work published by the group of Daniel Resasco at the University of Oklahoma [80], for fuel production rather than chemicals. In addition, much of the published literature focuses on simpler chemical representatives of the methyl esters from soybean oil; but these results are directly applicable to the production of chemical feedstocks, such as the synthesis of ethylbenzene that can be used for a variety of products: polymers, solvents, and reagents [77]. Although differences in the product distribution would be expected from TAG and single methyl ester conversions, comparison studies carried out by Kubatova and colleagues [46-48] on individual acylglycerides, as well as soybean mixtures, showed similar conversion chemistry.

Because it appears as if the products from these deoxygenation processes will require further processing to make fuels or chemical feedstocks, the FCC of triglycerides has been studied by groups such as Melero and colleagues [81]. In particular, the effect of soy-based 
biomass on the FCC process is of interest. Melero investigated both the cracking of $100 \%$ soybean oil, and a mixture of $30 \%$ soybean oil with petroleum, the latter being a typical feedstock for an oil refinery. The feed injection was held at $70^{\circ} \mathrm{C}$, but the FCC itself was carried out at $560^{\circ} \mathrm{C}$, representing typical conditions in a refinery. The boiling point range for the soybean biodiesel was from 545.7 to $636.0^{\circ} \mathrm{C}$ in comparison with the diesel range from $200-330^{\circ} \mathrm{C}$ [82]. Because of the unsaturated chains in the soybean oil, the aromatic fraction in the product was enhanced relative to that of pure petroleum, but the PAH was reduced. Saturated fatty acid fragments gave rise to light alkanes, light oil, and diesel fractions. There could be some concern about enhanced corrosion in the cracker because of the presence of the FFA, but research suggests that the lifetime of these compounds is very short at these temperatures, and so they may not present a problem. Many of the FCC products are similar from acylglycerides and petroleum, although the composition distributions are different. In the case the biomass, of FCC products come from reactions in the cracker and in the case of petroleum, most hydrocarbons are present in the original feedstock. Issues such as gum formation or the effect of impurities, such as entrained alkali metals that could be present in biological materials, were not studied by Melero [81].

\section{Conclusions}

Although many chemical pathways have been demonstrated in the laboratory, the scale-up to handle large quantities of bio-derived material presents a number of challenges in comparison with petroleum refining. These range from additional transportation costs because of distributed feedstock production, to catalyst cost and regeneration. Seasonal variations in the cultivation and harvesting of soybeans and production of oil can result to chemical changes in the feedstock material and minor components. However, it appears as if the chemical modification processes are robust to minor changes in FFA distribution. Impurities and their impact on catalyst performance and lifetime may be significant and difficult to test outside of an industrial setting. Impurity and effects of minor components are highly dependent on unpredictable phenomena such as feedstock composition or process variability. Thus, these effects may not appear, much less be quantified, in a bench-scale operation using laboratory grade chemicals. Hence, operation of pilot and demonstration scale facilities will be very informative. The feasibility of the production of hydrocarbons from soybean triglycerides or methyl esters derived from these triglycerides is often dependent on the availability of low cost hydrogen. Other technical hurdles include the optimization of interfacial reactions and separations before soybean oil can make a significant contribution to the hydrocarbon economy. The question of whether feedstocks from soybean oil should be introduced into a stream in an oil refinery, or converted in a small scale refinery to fungible products depends on the final application and cost issues. However, once converted to hydrocarbons, separations to commodity chemicals or fuel should be analogous to handling conventional petroleum products. 


\section{Nomenclature and abbreviations}

ASTM - American Society of Testing and Materials

BHA - butylatedhydroxyanisole

BHT - butylatedhydroxytoluene

FAME - Fatty Acid Methyl Esters

FCC - Fluidized Catalytic Cracking

FFA - Free Fatty Acid (monoglyceride)

HDO - Hydrodeoxygenation

LHSV - Liquid hourly space velocity

PAH - Polyaromatic Hydrocarbon

TAG- Triacylglyercol or triglyceride

TBHQ- Tert-butyl hydroquinone

WHSV - Weight hourly space velocity

\section{Acknowledgements}

Oak Ridge National Laboratory is managed by UT-Battelle, LLC, for the U.S. Department of Energy under contract DE-AC05-00OR22725.

\section{Author details}

Joanna McFarlane

Energy and Transportation Science Division, Oak Ridge National Laboratory, Oak Ridge, USA

\section{References}

[1] A. McIlroy and G. McRae, Basic Research Needs for Clean and Efficient Combustion of 21st Century Transportation Fuels. 2006.

[2] USEPA. RFS2 - Federal Policy Drivers for Increased Biofuels Usage. US Environmental Protection Agency, January 2009, accessed August 1, 2012; 
[3] EIA. Monthly Biodiesel Production Report. May 2012, accessed August 1 2012;

[4] API. US Oil Shale: Our Energy Resource, Our Energy Security, Our Choice. 2011, accessed Aug 1, 2012; Available from: http://www.api.org/ /media/Files/Oil-and-Natural-Gas/Oil_Shale/Oil_Shale_Factsheet_1.ashx.

[5] D.J. Murphy, Oil Crops as Potential Sources of Biofuels, in Technological Innovations in Major World Oil Crops, S.K. Gupta, Editor. 2012, Springer: NY. p. 269-284.

[6] S. Bezergianni, S. Voutetakis, and A. Kalogianni, "Catalytic Hydrocracking of Fresh and Used Cooking Oil".Industrial \& Engineering Chemistry Research, 2009. 48(18): p. 8402-8406.

[7] J. McFarlane, Processing of Soybean Oil into Fuels, in Recent Trends for Enhancing the Diversity and Quality of Soybean Products, D. Krezhova, Editor. 2011, InTech.

[8] J. McFarlane, C. Tsouris, J.F.J. Birdwell, Jr., D.L. Schuh, H.L. Jennings, A.M. PahmerBoitrago, and S.M. Terpstra, "Production of Biodiesel at Kinetic Limit Achieved in a Centrifugal Reactor/Separator".Industrial and Engineering Chemistry Research 2010. 49: p. 3160-3169.

[9] X.-W. Zhang and A. McWhirter, Conserving Fossil Fuel Resources Using Reaction Simulations to Maximize Biodiesel Production. 2012, Oak Ridge High School: Oak Ridge.

[10] M.S. Manic, V. Najdanovic-Visak, M.N. da Ponte, and Z.P. Visak, "Extraction of Free Fatty Acids from Soybean Oil Using Ionic Liquids or Poly(ethyleneglycol)S".Aiche Journal, 2011. 57(5): p. 1344-1355.

[11] C. Komintarachat and S. Chuepeng, "Solid Acid Catalyst for Biodiesel Production from Waste Used Cooking Oils".Industrial E Engineering Chemistry Research, 2009. 48(20): p. 9350-9353.

[12] MatLab. 2010, Mathworks: Natick, MA.

[13] A. Baig and F.T.T. Ng, "A Single-Step Solid Acid-Catalyzed Process for the Production of Biodiesel from High Free Fatty Acid Feedstocks". Energy E Fuels, 2010. 24: p. 4712-4720.

[14] V.K. Chakravarthy, J. McFarlane, C.S. Daw, Y. Ra, J.K. Griffin, and R. Reitz, "Physical Properties of Soy Bio-Diesel and N-Heptane: Implications for Use of Bio-Diesel in Diesel Engines".SAE 2007 Transactions, Journal of Fuels and Lubricants, 2008. 116: p. 885-895.

[15] Y. Ra, R.D. Reitz, J. McFarlane, and C.S. Daw, "Effects of Fuel Physical Properties on Diesel Engine Combustion Using Diesel and Bio-Diesel Fuels".SAE International Journal of Fuels and Lubricants, 2009. 1(1): p. 703-718.

[16] G.W. Mushrush, J.H. Wynne, H.D. Willauer, C.T. Lloyd, J.M. Hughes, and E.J. Beal, "Recycled Soybean Cooking Oils as Blending Stocks for Diesel Fuels".Industrial \& Engineering Chemistry Research, 2004. 43(16): p. 4944-4946. 
[17] G.W. Mushrush, J.H. Wynne, J.M. Hughes, E.J. Beal, and C.T. Lloyd, "Soybean-Derived Fuel Liquids from Different Sources as Blending Stocks for Middle Distillate Ground Transportation Fuels".Industrial \& Engineering Chemistry Research, 2003. 42(11): p. 2387-2389.

[18] D.L. Purcell, B.T. McClure, J. McDonald, and H.N. Basu, "Transient Testing of Soy Methyl Ester Fuels in an Indirect Injection, Compression Ignition Engine".Journal of the American Oil Chemists Society, 1996. 73(3): p. 381-388.

[19] R. Ashen, K.C. Cushman, and J. McFarlane, Chemical Kinetic Simulation of the Combustion of Bio-Based Fuels. in press, Oak Ridge National Laboratory: Oak Ridge TN.

[20] B. Bunting, M. Bunce, T. Barone, and J. Storey, Fungible and Compatible Biofuels: Literature Search, Summary, and Recommendations. 2010, Oak Ridge National Laboratory: Oak Ridge, TN.

[21] J. Risher, Toxilogical Profile for Fuel Oils. 1995, Sciences International, Inc: Research Triangle Institute

[22] T.A. Foglia, K.C. Jones, and J.G. Phillips, "Determination of Biodiesel and Triacylglycerols in Diesel Fuel by Liquid Chromatography".Chromatographia, 2005. 62(3-4): p. 115-119.

[23] ASTM, Specification for Diesel Fuel Oil, Biodiesel Blend (B6 to B20). 2008, American Society of Testing and Materials.

[24] D. Mackay, Illustrated Handbook of Physical Chemical Properties and Environmental Fate for Organic Chemicals. Vol. 5. 1997, Boca Raton, FL: Lewis Publishers.

[25] J. Sangster, "Octanol-Water Partition Coefficients". Journal of Physical and Chemical Reference Data, 1989. 18(3): p. 1111-1230.

[26] H.B. Krop, M.J.M. van Velzen, J.R. Parsons, and H.A.J. Govers, "N-Octanol-Water Partition Coefficients, Aqueous Solubilities and Henry's Law Constants of Fatty Acid Esters". Chemosphere, 1997. 34(1): p. 107-119.

[27] USEPA. Chemicals in the Environment: OPPT Chemical Fact Sheets. October 5, 2010; Available from: http://www.epa.gov/chemfact/.

[28] G.R. Stansell, V.M. Gray, and S.D. Sym, "Microalgal Fatty Acid Composition: Implications for Biodiesel Quality". Journal of Applied Phycology, 2012. 24(4): p. 791-801.

[29] C.P. Tan and Y.B.C. Man, "Differential Scanning Calorimetric Analysis for Monitoring the Oxidation of Heated Oils".Food Chemistry, 1999. 67(2): p. 177-184.

[30] G. Knothe, "Some Aspects of Biodiesel Oxidative Stability".Fuel Processing Technology, 2007. 88(7): p. 669-677.

[31] R.C. Simas, D. Barrrera-Arellano, M.N. Eberlin, R.R. Catharino, V. Souza, and R.M. Alberici, "Triacylglycerols Oxidation in Oils and Fats Monitored by Easy Ambient 
Sonic-Spray Ionization Mass Spectrometry". Journal of the American Oil Chemists Society, 2012. 89: p. 1193-1200.

[32] T.D. Crowe and P.J. White, "Adaptation of the AOCS Official Method for Measuring Hydroperoxides from Small-Scale Oil Samples". Journal of the American Oil Chemists Society, 2001. 78(12): p. 1267-1269.

[33] E.N. Frankel, "Lipid Oxidation: Mechanisms, Products and Biological Significance". Journal of the American Oil Chemists Society, 1984. 61(12): p. 1908-1917.

[34] N. Canha, P. Felizardo, J.C. Menezes, and M.J.N. Correira, "Multivariate near Infrared Spectroscopy Models for Predicting the Oxidative Stability of Biodiesel: Effect of Antioxidants Addition".Fuel, 2012. 97: p. 352-357.

[35] T.S. Yang, Y.H. Chu, and T.T. Liu, "Effects of Storage Conditions on Oxidative Stability of Soybean Oil". Journal of the Science of Food and Agriculture, 2005. 85(9): p. 1587-1595.

[36] S. Schober and M. Mittelbach, "The Impact of Antioxidants on Biodiesel Oxidation Stability". European Journal of Lipid Science and Technology, 2004. 106(6): p. 382-389.

[37] G. Knothe, "A Technical Evaluation of Biodiesel from Vegetable Oils Vs. Algae. Will Algae-Derived Biodiesel Perform?". Green Chemistry, 2011. 13(11): p. 3048-3065.

[38] I. Kriston, A. Orban-Mester, G. Nagy, P. Staniek, E. Foldes, and B. Pukanszky, "Melt Stabilisation of Phillips Type Polyethylene, Part I: The Role of Phenolic and Phosphorous Antioxidants".Polymer Degradation and Stability, 2009. 94: p. 719-729.

[39] D. Lomonaco, F.J.N. Maia, C.S. Clemente, J.P.F. Mota, A.E.J. Costa, and S.E. Mazzetto, "Thermal Studies of New Biodiesel Antioxidants Synthesized from a Natural Occurring Phenolic Lipid".Fuel, 2012. 97: p. 552-559.

[40] A. Günther, T. König, W.D. Habicher, and K. Schwetlick, "Antioxidant Action of Organic Sulphites-I. Esters of Sulphurous Acid as Secondary Antioxidants ". Polymer Degradation and Stability, 1997. 55: p. 209-216.

[41] T.V. Choudhary and C.B. Phillips, "Renewable Fuels Via Catalytic Hydrodeoxygenation". Applied Catalysis A: General, 2011. 397(1-2): p. 1-12.

[42] T. Morgan, D. Grubb, E. Santillan-Jimenez, and M. Crocker, "Conversion of Triglycerides to Hydrocarbons over Supported Metal Catalysts". Topics in Catalysis, 2010. 53(11-12): p. 820-829.

[43] D. Jovanovic, R. Radovic, L. Mares, M. Stankovic, and B. Markovic, "Nickel Hydrogenation Catalyst for Tallow Hydrogenation and for the Selective Hydrogenation of Sunflower Seed Oil and Soybean Oil". Catalysis Today, 1998. 43(1-2): p. 21-28.

[44] C. Perego and A. Bosetti, "Biomass to Fuels: The Role of Zeolite and Mesoporous Materials". Microporous and Mesoporous Materials, 2011. 144(1-3): p. 28-39. 
[45] V. Calemma, S. Peratello, and C. Perego, "Hydroisomerization and Hydrocracking of Long Chain N-Alkanes on Pt/Amorphous Sio2-A12o3 Catalyst". Applied Catalysis A: General, 2000. 190(1-2): p. 207-218.

[46] A. Kubatova, J. St'avova, W.S. Seames, Y. Luo, S.M. Sadrameli, M.J. Linnen, G.V. Baglayeva, I.P. Smoliakova, and E.I. Kozliak, "Triacylglyceride Thermal Cracking: Pathways to Cyclic Hydrocarbons". Energy \& Fuels, 2012. 26(1): p. 672-685.

[47] Y. Luo, I. Ahmed, A. Kubatova, J. St'avova, T. Aulich, S.M. Sadrameli, and W.S. Seames, "The Thermal Cracking of Soybean/Canola Oils and Their Methyl Esters". Fuel Processing Technology, 2010. 91(6): p. 613-617.

[48] A. Kubatova, Y. Luo, J. St'avova, S.M. Sadrameli, T. Aulich, E. Kozliak, and W. Seames, "New Path in the Thermal Cracking of Triacylglycerols (Canola and Soybean Oil)".Fuel, 2011. 90(8): p. 2598-2608.

[49] D. Kubicka and L. Kaluza, "Deoxygenation of Vegetable Oils over Sulfided Ni, Mo and Nimo Catalysts".Applied Catalysis A: General, 2010. 372: p. 199-208.

[50] S. Kovács, T. Kasza, A. Therneszb, I.W. Horváth, and J. Hancsók, "Fuel Production by Hydrotreating of Triglycerides on Nimo/Al2o3/F Catalyst". Chemical Engineering Journal, 2011. 176-177: p. 237-243.

[51] O.V. Kikhtyanin, A.E. Rubanov, A.B. Ayupov, and G.V. Echevsky, "Hydroconversion of Sunflower Oil on Pd/SAPO-31 Catalyst". Fuel, 2010. 89(10): p. 3085-3092.

[52] T.M. Sankaranarayanana, M. Banub, A. Pandurangana, and S. Sivasanker, "Hydroprocessing of Sunflower Oil-Gas Oil Blends over Sulfided Ni-Mo-Al-Zeolite Beta Composites". Bioresource Technology, 2011. 102(22): p. 10717-10723.

[53] R. Sotelo-Boyas, Y. Liu, and T. Minowa, "Renewable Diesel Production from the Hydrotreating of Rapeseed Oil with Pt/Zeolite and $\mathrm{Nimo} / \mathrm{Al}_{2} \mathrm{O}_{3}$ Catalysts". Industrial $\mathcal{E}$ Engineering Chemistry Research, 2010. 50: p. 2791-2799.

[54] M. Krár, S. Kovács, D. Kalló, and J. Hancsók, "Fuel Purpose Hydrotreating of Sunflower Oil on Como/ $\mathrm{Al}_{2} \mathrm{O}_{3}$ Catalyst". Bioresource Technology, 2010. 10(23): p. 92879293.

[55] O.İ. Şenol, T.-R. Viljava, and A.O.I. Krause, "Effect of Sulphiding Agents on the Hydrodeoxygenation of Aliphatic Esters on Sulphided Catalysts". Applied Catalysis A: General, 2007. 326(2): p. 236-244.

[56] J. Myllyaja, P. Aalto, and E. Harlin, Process for the Manufacture of Diesel Range Hydrocarbons, WPTO, Editor. 2007, Neste Oil OYJ: Finland.

[57] J. Lane. Renewable Diesel Roundup. 2012 May 9, accessed August 1, 2012; Available from: http://www.altenergystocks.com/archives/2012/05/renewable_diesel_roundup_1.html.

[58] eco-business.com. Singapore: Exxonmobil to Raise 'Green' Diesel Output. 2010 November 10, accessed August 1, 2012; Available from: Nov. 24 2010, The Business Times, 
http://www.eco-business.com/news/singapore-exxonmobil-raise-green-diesel-output/.

[59] J. McFarlane, J.A. Gluckstein, M. Hu, M. Kidder, C. Narula, and M. Sturgeon, "Investigation of Catalytic Pathways and Separations for Lignin Breakdown into Monomers and Fuels". Separation Science and Technology, 2012. in press.

[60] B. Ozgen, "New Biodegradable Fibres, Yarn Properties and Their Applications in Textiles: A Review". Industrial Textila, 2012. 63(1): p. 3-7.

[61] S. Huda, N. Reddy, D. Karst, W.J. Xu, W. Yang, and Y.Q. Yang, "Nontraditional Biofibers for a New Textile Industry". J. Biobased Materials and Bioenergy, 2007. 1(2): p. 177-190.

[62] Y. Zhang, S. Ghasemzadeh, A.M. Kotliar, S. Kumar, S. Presnell, and L.D. Williams, "Fibers from Soybean Protein and Poly(Vinyl Alcohol)". J. Appl. Polymer Sci., 1999. $71(1)$.

[63] Y. Li, N. Reddy, and Y. Yang, "A New Crosslinked Protein Fiber from Gliadin and the Effect of Crosslinking Parameters on Its Mechanical Properties and Wataer Stability". Polymer International, 2008. 57: p. 1174-1181.

[64] N. Reddy and Y. Yang, "Natural Cellulose Fibers from Soybean Straw". Bioresource Technology, 2009. 100(14): p. 3593-3598.

[65] B. Karki, D. Maurere, S. Box, T.H. Kim, and S. Jung, "Ethanol Production from Soybean Fiber, a Co-Product of Aqueous Oil Extraction, Using a Soaking in Aqueous Ammonia Pretreatment". Journal of the American Oil Chemists Society, 2012. 89(7): p. 1345-1353.

[66] A.A. Boateng, C.A. Mullen, N.M. Goldberg, K.B. Hicks, T.E. Devine, I.M. Lima, and J.E. McMurtrey, "Sustainable Production of Bioenergy and Biochar from the Straw of High-Biomass Soybean Lines Via Fast Pyrolysis". Environmental Progress \& Sustainable Energy, 2010. 29(2): p. 175-183.

[67] D.A. Babb, Polyurethanes from Renewable Resources, in Synthetic Biodegradable Polymers, B. Rieger, et al., Editors. 2012. p. 315-360.

[68] B.K. Ahn, S. Kraft, D. Wang, and X.S. Sun, "Thermally Stable, Transparent, PressureSensitive Adhesives from Epoxidized and Dihydroxyl Soybean Oil". Biomacromolecules, 2011. 12(5): p. 1839-1843.

[69] G. Lligadas, J.C. Ronda, M. Galia, and V. Cadiz, "Plant Oils as Platform Chemicals for Polyurethane Synthesis: Current State-of-the-Art". Biomacromolecules, 2010. 11(11): p. 2825-2835.

[70] L. Hojabri, X.H. Kong, and S.S. Narine, "Fatty Acid-Derived Dilsocyanate and Biobased Polyurethane Produced from Vegetable Oil: Synthesis, Polymerization, and Characterization". Biomacromolecules, 2009. 10(4): p. 884-891. 
[71] P. Tran, D. Graiver, and R. Narayan, "Biocomposites Synthesized from Chemically Modified Soy Oil and Biofibers".J. Appl. Polymer Sci., 2006. 102(1): p. 69-75.

[72] R. Vendamme, K. Olaerts, M. Gomes, M. Degens, T. Shigematsu, and W. Eevers, "Interplay between Viscoelastic and Chemical Tunings in Fatty-Acid-Based Polyester Adhesives: Engineering Biomass toward Functionalized Step-Growth Polymers and Soft Networks". Biomacromolecules, 2012. 13(6): p. 1933-1944.

[73] G.H. Teng, J.R. Wegner, G.J. Hurtt, and M.D. Soucek, "Novel Inorganic/Organic Hybrid Materials Based on Blown Soybean Oil with Sol-Gel Precursors". Progress in Organic Coatings, 2001. 42(1-2): p. 29-37.

[74] A. Biswas, B.K. Sharma, J.L. Willett, S.Z. Erhan, and H.N. Cheng, "Soybean Oil as a Renewable Feedstock for Nitrogen-Containing Derivatives". Energy \& Environmental Science, 2008. 1(6): p. 639-644.

[75] K.V. Camarda and P. Sunderesan, "An Optimization Approach to the Design of Value-Added Soybean Oil Products". Industrial \& Engineering Chemistry Research, 2005. 44(4361-4367).

[76] K.D. Maher and D.C. Bressler, "Pyrolysis of Triglyceride Materials for the Production of Renewable Fuels and Chemicals". Bioresource Technology, 2007. 98: p. 2351-2368.

[77] T. Danuthai, S. Jongpatiwut, T. Rirksomboon, S. Osuwan, and D.E. Resasco, "Conversion of Methylesters to Hydrocarbons Over an H-ZSM5 Zeolite Catalyst H-Zsm5 Zeolite Catalyst". Applied Catalysis A: General, 2009. 361: p. 99-105.

[78] B. Donnis, R.G. Egeberg, P. Blom, and K.G. Knudsen, "Hydroprocessing of Bio-Oils and Oxygenates to Hydrocarbons. Understanding the Reaction Routes". Topics in Catalysis, 2009. 52(3): p. 229-240.

[79] G.W. Huber, S. Iborra, and A. Corma, "Synthesis of Transportation Fuels from Biomass: Chemistry, Catalysts, and Engineering". Chemical Reviews, 2006. 106(9): p. 4044-4098.

[80] T. Sooknoi, T. Danuthai, L.L. Lobban, R.G. Mallinson, and D.E. Resasco, "Deoxygenation of Methylesters over CsNaX". Journal of Catalysis, 2008. 258: p. 199-209.

[81] J.A. Melero, M.M. Clavero, G. Calleja, A. Garcia, R. Miravalles, and T. Galindo, "Production of Biofuels Via the Catalytic Cracking of Mixtures of Crude Vegetable Oils and Nonedible Animal Fats with Vacuum Gas Oil". Energy \& Fuels, 2010. 24: p. 707-717.

[82] R.W. Hurn and H.M. Smith, "Hydrocarbons in the Diesel Boiling Range". Industrial \& Engineering Chemistry, 1951. 43(12): p. 2788-2793. 
